UDC $332.02+336.02$

LBC 65.9

\title{
TAX BENEFITS FOR REGIONAL BUSINESS: NEED, SUFFICIENCY, EFFICIENCY
}

\author{
Irina P. Dovbiy \\ South Ural State University (National Research University), Chelyabinsk, Russian Federation \\ Diba M. Dokhkilgova \\ Chechen State University, Grozny, Russian Federation \\ Natalya S. Dovbiy \\ South Ural State University (National Research University), Chelyabinsk, Russian Federation
}

\begin{abstract}
The article analyzes the tax benefits for the enterprises of Russia. Their analysis is carried out in the context of territorial affiliation of tax benefit. Tax benefits were granted as anti-crisis measures: promotion of entrepreneurship, reduction of informal employment, implementation of investment projects. Their granting was often characterized by haphazard nature. There were cases of abuse in the application of tax benefits. The entrepreneur must be ready to prove their right to benefits.

Tax benefits have a triple effect: economic, fiscal-budgetary, social. The state tax policy allowed reducing the level of debt burden for 2016. Simultaneously, the increase in tax and non-tax revenues of the consolidated budgets was ensured. The authors analyze the regional and sectoral tax benefits. They are very diverse, especially for small businesses. This is due to socio-economic differentiation of regions. The magnitude of the regional tax burden is determined by the complex of factors: external and internal.

The application of tax benefits is associated with big problems. First of all, this is a concealment of income. Secondly, there is a problem of "double" taxation. Difficulties are also associated with applying individual tax regimes: special economic zones, territories of advanced development. The problem of drawing "out of the shadow" of selfemployed citizens is very acute. There must be a special fee regime for them: there is no guarantee of employment for such citizens. The problems of regional taxation of entrepreneurial activity include, on the one hand, the availability and development of various benefits, and on the other hand, their nonsystem character, the impossibility of identifying and using various mechanisms in the aggregate, for example, the mechanisms for the development of entire industries $\sim$ and social directions in entrepreneurship. The authors emphasize that the conditions in which the modern economy $\vec{\sim}$ of Russia is developing, actualize the task of analyzing the effectiveness of tax benefits.

i. Key words: regional taxation, business taxation, free economic zones, tax collection, tax burden, special regime of taxation, tax incentives, efficiency.

УДК $332.02+336.02$

ББК 65.9
\end{abstract}

НАЛОГОВЫЕ ЛЬГОТЫ ДЛЯ РЕГИОНАЛЬНОГО ПРЕДПРИНИМАТЕЛЬСТВА: НЕОБХОДИМОСТЬ, ДОСТАТОЧНОСТЬ, ЭФФЕКТИВНОСТЬ

\author{
Ирина Павловна Довбий \\ Южно-Уральский государственный университет (НИУ), г. Челябинск, Российская Федерация \\ Диба Мажитовна Дохкильгова \\ Чеченский государственный университет, г. Грозный, Российская Федерация
}




\section{Наталья Сергеевна Довбий}

Южно-Уральский государственный университет (НИУ), г. Челябинск, Российская Федерация

Аннотация. В статье анализируются налоговые льготы для субъектов российского предпринимательства. Проводится их анализ в контексте территориальной принадлежности налоговой льготы. Налоговые льготы принимались в качестве антикризисных мер для стимулирования предпринимательства, снижения неформальной занятости и реализации инвестиционных проектов. Зачастую их принятие было бессистемным. Имели место случаи злоупотреблений при применении налоговых льгот. Предприниматель должен быть готов доказать свое право на льготы.

Налоговые льготы обладают тройным эффектом: экономическим, фискально-бюджетным и социальным. Государственная налоговая политика позволила сократить уровень долговой нагрузки за 2016 год. Одновременно был обеспечен рост налоговых и неналоговых доходов консолидированных бюджетов. Авторы проанализировали региональные и отраслевые налоговые льготы. Они отличаются большим разнообразием, особенно для субъектов малого бизнеса. Это обусловлено социально-экономической дифференциацией регионов. Величина же налоговой нагрузки региона определяется комплексом факторов: внешних и внутренних.

Применение налоговых льгот сопряжено с большими проблемами. Прежде всего это сокрытие доходов. Не менее проблемно «двойное» налогообложение. Существуют сложности применения отдельных налоговых режимов: особые экономические зоны, территории опережающего развития. Остро стоит проблема вывода «из тени» самозанятых граждан. Для них должен быть предусмотрен особый режим сборов: нет гарантии занятости таких граждан. Проблемы регионального налогообложения предпринимательской деятельности заключаются, с одной стороны, в наличии и развитии различных льгот, а с другой - в их бессистемности, невозможности идентификации и использования различных механизмов в совокупности, например, механизмов развития целых отраслей и социальных направлений в предпринимательстве. Авторами особо подчеркивается, что условия, в которых находится современная экономика России, актуализируют задачу анализа эффективности применения налоговых льгот.

Ключевые слова: региональное налогообложение, налогообложение предпринимательской деятельности, свободные экономические зоны, собираемость налогов, налоговая нагрузка, специальный режим налогообложения, налоговое стимулирование, эффективность.

Ежегодная подготовка федерального бюджета России на очередной год, сопряженная с необходимостью ограничения бюджетных расходов, приковывает внимание Минфина, Федеральной налоговой службы и Счетной палаты к налоговым льготам. Их предоставление экономическим субъектам фактически означает опосредованное финансирование налогоплательщиков из бюджета. Возникает дилемма: отказ от налоговых льгот обеспечивает приток налоговых доходов в бюджет для решения социально-экономических задач; предоставление налоговых льгот имеет следствием уменьшение налоговых поступлений в доходную часть бюджета. Налоговая политика государства, как правило, направлена на улучшение инвестиционного климата, стимулирование притока инвестиций, увеличение выпуска продукции, сокращение безработицы, повышение благосостояния граждан [4; $17 ; 19]$. Однако в России при разработке основных направлений социально-экономического развития зачастую не проводится необхо- димый анализ эффективности налоговых льгот, их влияния на экономический рост. Налоговые маневры выступают инструментом антикризисных мер. Особую актуальность имеют налоговые льготы для предпринимательских структур, выступающих основой социально-экономического развития регионов $[2 ; 3 ; 7]$.

Резкое изменение внешнеэкономической конъюнктуры в середине 2014 г., обусловленное снижением цен на нефть, нарастанием геополитической напряженности и падением покупательной способности рубля, потребовало от правительства принятия пакета антикризисных мер, в числе которых особое место отведено снижению налоговой нагрузки не только на субъекты экономической деятельности (малый, средний и крупный бизнес), но и на отдельные территории (особые экономические зоны и территории опережающего развития).

С целью преодоления кризисных явлений и нивелирования внешних шоков Распоряжением Правительства РФ от 27.01.2015 г. № 98-р 
был принят ряд налоговых льгот отраслевого и территориального характера. По внутренним воздушным перевозкам была установлена ставка налога на добавленную стоимость $10 \%$, по пригородным железнодорожным 0 \%. Субъектам Российской Федерации было предоставлено право в отношении субъектов малого бизнеса, применяющих специальные режимы налогообложения $(\mathrm{CPH})$ с целью высвобождения инвестиционных и дополнительных оборотных средств:

- микропредприятиям, применяющим упрощенную систему налогообложения с объектом налогообложения «доходы», - снижать ставки налога с 6 до $1 \%$;

- индивидуальным предпринимателям, применяющим патентную систему налогообложения (ПСН), снижать в два раза максимальный размер потенциально возможного к получению индивидуальным предпринимателем годового дохода (с 1 млн рублей до 500 тыс. рублей);

- налогоплательщикам, применяющим систему налогообложения в виде единого налога на вмененный доход для отдельных видов деятельности, ставки могут быть снижены с 15 до 7,5\%.

Для стимулирования субъектов Федерации к расширению применения налогоплательщиками СРН из оценки налогового потенциала регионов при расчете объемов межбюджетных трансфертов исключались доходы, получаемые в результате применения СРН.

Основными направлениями налоговой политики Российской Федерации на 2016 г. и на период 2017-2018 гг. с целью ускорения реализации региональных инвестиционных проектов в ряде регионов России (Забайкалье, Дальний Восток), а также для ряда резидентов Пермского края и Карачаево-Черкесской Республики предусмотрен «налоговый маневр» по налогу на добычу полезных ископаемых, налогу на прибыль.

С целью снижения неформальной занятости в сфере малого предпринимательства для самозанятых граждан государством предусматривается комплекс льгот, обеспечивающих плавный старт предпринимательской деятельности:

- впервые зарегистрированным индивидуальным предпринимателям в сфере произ- водственных и бытовых услуг предусмотрены двухлетние «налоговые каникулы»;

- установлена возможность уплаты самозанятыми гражданами налога в связи с применением патентной системы налогообложения и обязательных платежей по страховым взносам одновременно с их регистрацией в качестве индивидуальных предпринимателей по принципу «одного окна», а также введение особого порядка исчисления и уплаты налога на доход физических лиц и страховых взносов в государственные внебюджетные фонды для самозанятых граждан, осуществляющих определенные виды приносящей доход деятельности без привлечения наемных работников и не зарегистрированных в качестве индивидуальных предпринимателей («патент для самозанятых граждан»).

Налоговые льготы коснулись и предпринимателей, занимающихся мелкосерийным производством, в частности расширен перечень видов деятельности, в рамках осуществления которых возможно применение патентной системы налогообложения.

В результате проводимой с 2015 г. государственной экономической политики, направленной на преодоление последствий внешних шоков и минимизацию потерь при переходе в равновесное состояние с новой структурой экономики ${ }^{1}$, к середине 2017 г. были достигнуты:

- крепкий платежный баланс с минимальной зависимостью от внешнего финансирования и ограниченной уязвимостью к волатильности мировых рынков;

- контролируемый уровень бюджетного дефицита с прозрачной траекторией перехода к сбалансированному бюджету;

- контролируемая инфляционная динамика и снижающиеся инфляционные ожидания [13].

Структурные изменения в национальной экономике и последовательная реализуемая политика в области межбюджетных отношений позволили существенно повысить сбалансированность региональных финансов и сократить уровень долговой нагрузки, в том числе за 2016 г.:

- снизить суммарный консолидированный дефицит бюджетов до 12,5 млрд рублей (меньше 2015 г. в 13,6 раза);

- обеспечить рост налоговых и неналоговых доходов консолидированных бюджетов 
на 8,7 \% (составили 8,3 трлн рублей), снижение безвозмездных поступлений на 2,9 \% (составили 1,6 трлн рублей);

- сократить количество «дефицитных субъектов» с 76 до 56 и величину объема дефицита с 371 до 201 млрд рублей;

- сократить уровень долговой нагрузки на 2,7 п.п. до 33,8 \% (отношение госдолга к собственным доходам регионов) и др.

В целом 33 регионам удалось улучшить свои позиции, 40 сдали свои позиции; 12 остались на прежних местах [14].

Налоговая нагрузка региона (территории) меняется под воздействием внешних и внутренних факторов, а также в определенные моменты времени подвергается влиянию преференций, налоговых льгот и иммунитетов. В числе внешних факторов, на которые не способны оказывать влияние органы власти субъектов РФ, следует назвать:

- мегаэкономические: глобализация и международная интеграция; динамика сырьевых и валютных рынков; внешнеэкономическая конъюнктура; политика государства в сфере международного налогообложения; иностранные инвестиции; внешнеэкономические санкции и контрсанкции и т. д.;

- макроэкономические: уровень инфляции и цен; курс национальной валюты, процентные ставки; государственная налоговая политика равнонапряженности федерального налогообложения регионов, уровень налогового администрирования и налоговой дисциплины; степень развитости финансово-банковской сферы, публичных и корпоративных финансов и т. д.;

Внутренние факторы формируются под воздействием исторических аспектов региональной налоговой политики и как отклик на деятельность региональных органов власти и управления:

- мезоэкономические: уровень и тенденции социально-экономического развития региона; межрегиональная экономическая интеграция; количественная и качественная структура населения; профильная направленность отраслей регионального хозяйства и т. д.;

- микроэкономические: финансовое состояние экономических субъектов; наличие просроченной кредиторской и налоговой задолженности; инвестиционная и производственная активность и т. д.
Налоговая политика и деятельность региональных органов власти имеет законодательно ограниченную самостоятельность в части государственной фискальной и финансовой политики. Налоговые льготы и преференции экономическим субъектам устанавливаются в пределах делегированных федеральными властями полномочий и специфики конкретной территории. При этом они должны обладать тройным эффектом: экономическим (повышение результатов финансово-хозяйственной и инвестиционной деятельности хозяйствующих субъектов-получателей налоговых льгот); фискально-бюджетным (прирост последующих налоговых доходов бюджета над текущими налоговыми расходами и экономия бюджетных средств); социальным (развитие инфраструктуры социальной сферы, создание рабочих мест, повышение заработной платы и уровня жизни населения).

Налоговые льготы в Российской Федерации отличаются значительным разнообразием, что обусловлено масштабами страны и социально-экономической дифференциацией регионов. В данной связи требуют решения проблемы регионального налогообложения предпринимательских структур [8]. Первой проблемой видится достаточно сильная дифференциация налогообложения в региональном разрезе: наличие значительных различий как в льготах по имущественным налогам, по налогу на прибыль, упрощенной системе налогообложения, так и в различных подходах к собираемости налогов, давлению на бизнес. Вторую проблему можно обозначить как объективную необходимость и потребность в оптимальном распределении федеральных, региональных и местных налогов и сборов [5]. Значимой проблемой является «двойной» объект налогообложения. Так, например, по налогу на имущество организаций в качестве объекта налогообложения признается движимое и недвижимое имущество, включая транспортные средства, которые в соответствии с НК РФ подлежат обложению транспортным налогом.

Целый ряд авторов обращают внимание на такую региональную проблему, как необходимость перераспределения налоговых поступлений на федеральном и региональном уровнях [11;12]. 
Существуют и проблемы налогообложения в конкретных специальных режимах. Упрощенная система налогообложения $(\mathrm{YCH})$ предназначена для упрощения налогообложения субъектов малого предпринимательства, однако налогоплательщики не могут признать все виды расходов как при общей системе налогообложения, регулируемой 26 главой НК РФ.

Единый налог на вмененный доход часто является «камнем раздора», и уже достаточно давно идет речь о том, чтобы эту систему налогообложения отменить. Также дискуссионными являются вопросы применения коэффициентов по данному налогу.

Сельскохозяйственный налог в 2017 г. лишился преференций в части пониженных ставок страховых взносов, в связи с чем стал менее привлекательным для предпринимателей и малого бизнеса ${ }^{2}$.

Целый ряд экономистов считают, что в России действует неэффективная система налогообложения подоходным налогом (НДФЛ), поскольку во всех развитых странах подоходный налог зависит от дохода предпринимателя или его семьи. Плоская шкала налогообложения не обеспечивает социальное равенство, которого стараются добиться в других странах. Поэтому несколько раз вносился на обсуждение законопроект, предполагающий введение в России, как и в других странах, НДФЛ, зависящего от доходов.

Еще одной проблемой является сокрытие доходов, в том числе самозанятыми гражданами, в связи с чем существует ряд предложений, в том числе в отношении сбора с таких граждан денежных средств в размере от 10 тыс. до 20 тыс. рублей за годовое социальное обеспечение. Однако эта идея не нашла поддержки в обществе, поскольку подобный сбор не гарантирует получение дохода или же обеспечение работой, заказами самозанятых граждан.

Существует проблема неэффективности существующих льгот. Это связано с тем, что эффективности льгот не дана надлежащая оценка, не ведется статистический учет введения льгот. При этом льготы на местном и региональном уровне не эффективны по той причине, что за регионами закреплены налоги, не имеющие соответствующего удельно- го веса в поступлениях консолидированных бюджетов. Удельный вес региональных поступлений составляет всего 15-20\%. Постоянное изменение налогообложения также не способствует долгосрочному развитию фискальной системы, увеличению поступлений в бюджет за счет повышения предпринимательской активности.

При исследовании налоговых льгот предпринимательских структур в региональном разрезе следует отметить, что они рассматриваются в двух аспектах: во-первых, льготы, предоставляемые территориям; во-вторых, льготы в налогообложении предпринимательской деятельности. Существуют также отраслевые виды льгот, например, можно выделить пониженные ставки налогов, которые предоставляются тем, кто использует труд инвалидов. Ряд регионов используют льготы при перевозке пассажиров, например, в г. Москве действуют льготы по перевозке пассажиров (кроме услуг такси). Также компании могут выбирать режимы налогообложения, например, использовать патент, который не могут применять юридические лица.

Российской налоговой политикой предусмотрены льготы для особых экономических зон, но на практике предприниматели отмечают определенные сложности, связанные с применением льгот и вхождением в свободную экономическую зону.

Прежде всего следует назвать особые экономические зоны (ОЭ3) ${ }^{3}$ со льготным режимом налогообложения, создаваемые в форме промышленно-производственных (ППТ 10), технико-внедренческих (ТВТ - 6), туристско-рекреационных (ТРТ-9) и портовых особых экономических зон (ПТ - 1). В числе задач создания ОЭЗ следует назвать нацеленность на высокотехнологичное производство и создание отраслей глубокой переработки с высокой добавленной стоимостью, обеспечивающих конкурентоспособность в глобальном экономическом пространстве. Компании-резиденты пользуются рядом налоговых преференций (по данным МЭР РФ, действующая сегодня в ОЭЗ система налогообложения обеспечивает выгоду в 20-30\%) [10;15].

Налоговый режим ОЭЗ предусматривает для всех резидентов гарантированный законодательством набор льгот [15]: 
- пониженная ставка налога на прибыль организаций: вместо 20 \% (общиеусловия) до 01.01 .2018 г. 13,5 \% и на весь период 15,5\%;

- нулевая ставка земельного налога в течение 10 лет с месяца, следующего за месяцем постановки на учет указанного имущества (2,2 \% по общим условиям);

- нулевая ставка налога на транспорт на срок в 5 лет с момента регистрации транспортного средства (общие условия - 10150 рублей за 1 лошадиную силу);

- ставки страховых взносов в фонды пенсионного, медицинского и социального страхования $14 \%$ до 31.12.2017 г., $21 \%$ - в 2018 г., $28 \%$ - в 2019 г. (30\% - общие условия).

На территории технико-внедренческой ОЭЗ применяется таможенная процедура свободной таможенной зоны.

Портовые экономические зоны создаются на территории морских и речных портов. Их резидентами признаются коммерческие организации, осуществляющие деятельность по созданию, реконструкции и эксплуатации объектов инфраструктуры порта. В настоящий момент в России создана одна ОЭЗ ПТ «Ульяновск» (Ульяновская область), однако по меньшей мере восемь субъектов Федерации могут выступать потенциальными территориями создания портовых особых экономических зон (см. рисунок). За период функциони- рования ОЭЗ в 2005-2016 гг. они показали крайне низкую эффективность и не стали, по замечанию Счетной палаты РФ, действенным инструментом экономического развития территорий [18]. Из федерального бюджета на их развитие было выделено в общей сложности 121,9 млрд рублей, из региональных - 64 млрд рублей, но лишь четыре из двадцати шести ОЭЗ обеспечили «относительную эффективность»: в г. Санкт-Петербурге, Республике Татарстан («Алабуга»), Липецкой ${ }^{4}$ и Самарской (ОЭЗ «Тольятти») областях ${ }^{5}$.

При указанных инвестициях было создано всего 21,1 тыс. рабочих мест. Стоимость одного рабочего места обошлась казне в 9,1 млн государственных рублей. Объем осуществленных резидентами инвестиций составил всего $33,5 \%$ от заявленного объема (217,7 млрд рублей). Величина таможенных преференций и налоговых льгот, полученных резидентами на этих территориях, составила 28 млрд рублей, государству вернулось в качестве платежей 38,8 млрд рублей [18].

По мнению аналитиков, в особых экономических зонах сформировался избыточный набор инструментов, при котором фактически теряется их экономический смысл господдержки и стимулирования. В числе причин низкой эффективности названных территорий называется приказной порядок их создания в

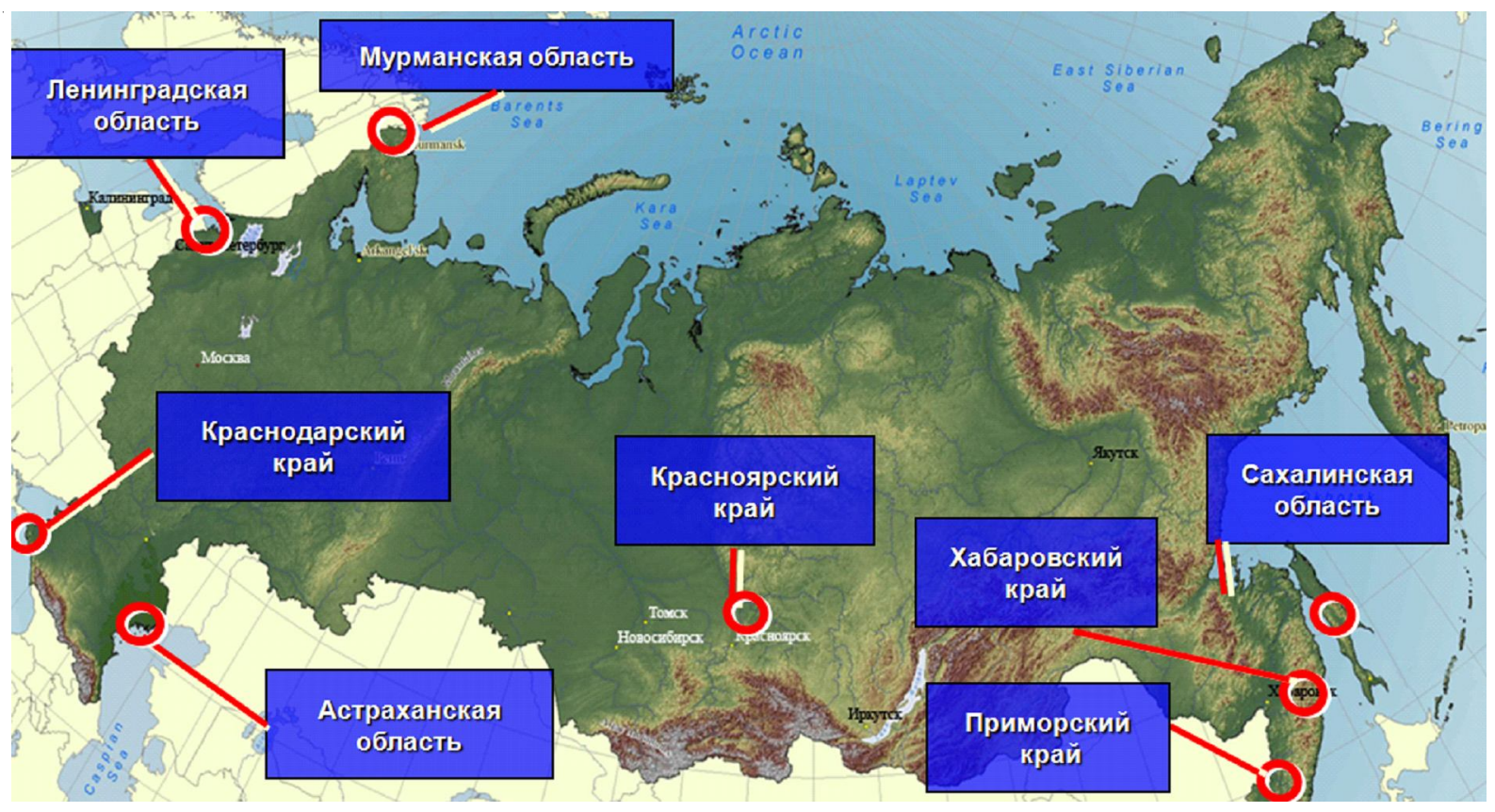

Рисунок. Потенциальные территории РФ по созданию портовых ОЭЗ 
местах, где еще не сформировались объективные условия для предпринимательской активности. «Накачка» деньгами привела к тому, что государственные финансовые ресурсы «разместились» на депозитах «приближенных» коммерческих банков, обеспечивая предсказуемый поток прибылей для покрытия текущей «сытой» деятельности управляющих компаний.

В свободных экономических зонах также возможно использовать льготные режимы налогообложения имущества и земли, а также приоритеты различных видов зон. В некоторых из них действуют налоговые каникулы, однако они распространяются не на всех предпринимателей, которые работают в такой зоне, а на тех, кто получает статус резидента, и действуют в течение 5-10 лет.

Особенностью внешнеэкономических зон является возможность получения различного рода поддержки, а не только налоговые преференции. Например, в качестве налоговых преференций можно назвать освобождение от налогообложения или снижение процентов по налогам для инвесторов. Кроме этого могут быть предусмотрены более низкие тарифы при таможенном оформлении, а также отмена пошлин. К административным льготам подобных зон относятся упрощение процесса регистрации, а также освобождение от административных барьеров, например, при выделении земли, подключении к энергоносителям. Также возможны преференции, предусматривающие возможность получения льгот, субсидий и кредитов.

Опыт низкой эффективности ОЭЗ был учтен при подготовке закона о территориях опережающего развития (TOP) ${ }^{6}$. Это территории в границах собственных муниципальных образований, для которых устанавливается «режим осуществления предпринимательской и иной деятельности в целях формирования благоприятных условий для привлечения инвестиций, обеспечения ускоренного социально-экономического развития и создания комфортных условий для обеспечения жизнедеятельности населения» [9]. Территории опережающего социально-экономического развития создаются по решению Правительства РФ на семьдесят лет.
Таким образом, сегодня можно говорить об определенной бюджетной эффективности деятельности лишь отдельных резидентов особых экономических зон, демонстрирующих налоговую отдачу, в то время как устойчивость социально-экономического развития региона во многом определяется наличием финансовых ресурсов: собственных и закрепленных доходов местных бюджетов, а также трансфертами из вышестоящих уровней бюджетной системы.

Некоторые регионы, такие как Крым, являются приоритетными, в том числе и в политике налогообложения. В Крыму действуют льготы как по налогу на прибыль, так и по упрощенной системе налогообложения. Индивидуальным предпринимателям, которые применяют объект «доходы за вычетом расходов» ставка налога была снижена до $3 \%$, такая ставка действует на протяжении 2017-2021 годов.

Кроме того, в субъектах Российской Федерации в настоящее время распространяется право устанавливать на период до 2020 г. на соответствующей территории налоговую ставку 0 \% для впервые зарегистрированных ИП, ведущих деятельность в производственной, социальной, научной и бытовой сферах и применяющих УСН или ПСН. Напомним, что так называемые «Налоговые каникулы» были введены с 2015 года. Но данная льгота имеет конечную дату применения, поэтому многие компании и предприниматели не очень рассчитывают на ее применение.

Перспективным направлением развития льгот является применение сниженных ставок по УСН. Многие регионы могут применять льготные ставки не только по объекту «доходы за минусом расходов», но и с 2016 г. по объекту «доходы». Льготы по упрощенной системе налогообложения в разрезе субъектов Федерации выглядят следующим образом (см. таблицу).

Из данных, приведенных в таблице, можно видеть, что далеко не все регионы воспользовались возможностью снижения налоговой нагрузки на региональный предпринимательский сектор. Между тем проблема налоговой поддержки быстрорастущих предприятий малого и среднего бизнеса в России актуальна как никогда [1]. 
И.П. Довбий, Д.М. Дохкильгова, Н.С. Довбий. Налоговые льготы для регионального предпринимательства

Региональные льготы по УСН

\begin{tabular}{|c|c|c|}
\hline Регион & Объект «Доходы минус расходы» & Объект «Доходы» \\
\hline Город Москва & $10 \%$ & не установлены \\
\hline Московская область & $10 \%$ & не установлены \\
\hline Город Санкт-Петербург & $\begin{array}{l}7 \text { \% - платят все налогоплательщики } \\
\text { независимо от вида деятельности }\end{array}$ & не установлены \\
\hline Ленинградская область & $\begin{array}{l}5 \% \text { - платят все налогоплательщики } \\
\text { независимо от вида деятельности }\end{array}$ & не установлены \\
\hline Республика Крым & $\begin{array}{l}10 \text { \% - платят все налогоплательщики } \\
\text { независимо от вида деятельности }\end{array}$ & $\begin{array}{l}4 \text { \% - платят все налогоплательщики } \\
\text { независимо от вида деятельности }\end{array}$ \\
\hline Город Севастополь & $\begin{array}{l}\text { От } 3 \text { до } 10 \% \\
10 \% \text { платят все остальные налогопла- } \\
\text { тельщики независимо от вида дея- } \\
\text { тельности }\end{array}$ & $4 \%$ \\
\hline Амурская область & $5 \%$ и $7,5 \%$ & $1 \%$ и $3 \%$ \\
\hline Астраханская область & $10 \%$ & не установлены \\
\hline Белгородская область & $5 \%$ & не установлены \\
\hline Брянская область & $12 \%$ & $3 \%$ \\
\hline Владимирская область & $5 \%, 8 \%$ и $10 \%$ & $4 \%$ \\
\hline Волгоградская область & $5 \%$ & не установлены \\
\hline Воронежская область & $5 \%$ & $4 \%$ \\
\hline EAO & $5 \%, 8 \%$ и $10 \%$ & не установлены \\
\hline Забайкальский край & $5 \%$ & не установлены \\
\hline Ивановская область & $5 \%$ & $4 \%$ \\
\hline Иркутская область & $5 \%$ и $7,5 \%$ & не установлены \\
\hline Кабардино-Балкарская Республика & $5 \%$ и $7 \%$ & не установлены \\
\hline Калужская область & $5 \%, 7 \%$ и $10 \%$ & не установлены \\
\hline Камчатский край & $10 \%$ & $1 \%, 2 \%, 3 \%, 4 \%$ и $5 \%$ \\
\hline Карачаево-Черкесская Республика & $9 \%$ & не установлены \\
\hline Кемеровская область & $5 \%$ и $15 \%$ & от $3 \%, 5 \%$ и $6 \%$ \\
\hline Кировская область & $6 \%$ & не установлены \\
\hline Костромская область & $10 \%$ & не установлены \\
\hline Краснодарский край & $5 \%$ & $3 \%$ \\
\hline Курганская область & $10 \%$ и $15 \%$ & не установлены \\
\hline Курская область & $5 \%$ & $5 \%$ \\
\hline Липецкая область & $5 \%$ & $5 \%$ \\
\hline Магаданская область & $7,5 \%$ & $3 \%$ \\
\hline Мурманская область & $5 \%, 10 \%$ и $15 \%$ & не установлены \\
\hline Ненецкий автономный округ & $5 \%, 10 \%$ и $15 \%$ & $1 \%, 3 \%$ и $6 \%$ \\
\hline Новгородская область & $10 \%$ & не установлены \\
\hline Оренбургская область & $10 \%$ & $5 \%$ \\
\hline Орловская область & $5 \%$ & не установлены \\
\hline Пензенская область & $5 \%$ & не установлены \\
\hline Пермский край & $5 \%$ и $10 \%$ & $1 \%$ и $4 \%$ \\
\hline Псковская область & $5 \%, 10 \%$ и $15 \%$ & не установлены \\
\hline Республика Адыгея & $5 \%$ и $15 \%$ & не установлены \\
\hline Республика Алтай & $5 \%$ & не установлены \\
\hline Республика Бурятия & $5 \%$ и $10 \%$ & $3 \%$ \\
\hline Республика Дагестан & 10 \% для всех налогоплательщиков & не установлены \\
\hline Республика Калмыкия & \begin{tabular}{|l}
$5 \%$ и $10 \%$ \\
$10 \%$ платят остальные категории
\end{tabular} & $1 \%$ и $6 \%$ \\
\hline
\end{tabular}


ФИНАНСЫ. БУХГАЛТЕРСКИЙ УЧЕТ

Окончание таблиць

\begin{tabular}{|c|c|c|}
\hline Регион & Объект «Доходы минус расходы» & Объект «Доходы» \\
\hline Республика Карелия & $\begin{array}{l}5 \%, 10 \% \text { и } 12,5 \% \text { для остальных ка- } \\
\text { тегорий }\end{array}$ & не установлены \\
\hline Республика Коми & \begin{tabular}{|l|}
10 \% налогоплательщики, которые \\
платят единый налог с разницы между \\
доходами и расходами и осуществляют \\
виды деятельности, указанные в при- \\
ложении к Закону. Доля доходов по \\
этим видам деятельности за отчетный \\
(налоговый) период должна составлять \\
не менее 85 \% в общем доходе
\end{tabular} & не установлены \\
\hline Республика Марий Эл & не установлены & не установлены \\
\hline Республика Мордовия & $5 \%$ и $15 \%$ & $1 \%$ и $6 \%$ \\
\hline Республика Саха (Якутия) & $5 \%$ и $10 \%$ & $2 \%, 4 \%$ и $6 \%$ \\
\hline Республика Северная Осетия & $10 \%$ & не установлены \\
\hline Республика Татарстан & $5 \%$ и $10 \%$ & не установлены \\
\hline Республика Тыва & $5 \%$ и $10 \%$ & $4 \%$ \\
\hline Республика Хакасия & $5 \%, 12 \%$ и $15 \%$ & $2 \%$ и $5 \%$ \\
\hline Ростовская область & $10 \%$ & $5 \%$ \\
\hline Рязанская область & $5 \%$ & не установлены \\
\hline Самарская область & \multicolumn{2}{|c|}{$\begin{array}{l}\text { Отменен региональный закон, устанавливавший дифференцированные став- } \\
\text { ки единого налога }\end{array}$} \\
\hline Саратовская область & $5 \%, 6 \%$ и $7 \%$ & $1 \%$ \\
\hline Сахалинская область & $10 \%$ & $3 \%$ \\
\hline Свердловская область & $5 \%$ и $7 \%$ & не установлены \\
\hline Смоленская область & $5 \%, 7 \%$ и $15 \%$ & не установлены \\
\hline Ставропольский край & $5 \%$ & не установлены \\
\hline Тамбовская область & $5 \%$ & $4 \%$ \\
\hline Томская область & $5 \%, 7,5 \%$ и $15 \%$ & $4,5 \%$ \\
\hline Тульская область & от $5 \%$ до $10 \%$ & от $1 \%$ до $3 \%$ \\
\hline Тюменская область & $\begin{array}{l}5 \text { \% в период с } 01.01 .2015 г \text { г. по } \\
31.12 .2019 г . \text { действует налоговая } \\
\text { ставка } 5 \text { \% для всех налогоплатель- } \\
\text { щиков }\end{array}$ & не установлены \\
\hline Удмуртская Республика & от $5 \%$ до $10 \%$ & не установлены \\
\hline Ульяновская область & от $5 \%$ до $10 \%$ & $1 \%$ \\
\hline Хабаровский край & $8 \%$ & не установлены \\
\hline XMAO & $\begin{array}{l}5 \text { \% - для налогоплательщиков, кото- } \\
\text { рые платят единый налог с разницы } \\
\text { между доходами и расходами и явля- } \\
\text { ются микропредприятиями, малыми } \\
\text { предприятиями }\end{array}$ & $5 \%$ \\
\hline Челябинская область & $10 \%$ & $3 \%$ \\
\hline Чеченская Республика & $\begin{array}{l}5 \% \text { установлена ставка для всех нало- } \\
\text { гоплательщиков, которые применяют } \\
\text { УСН с объектом «Доходы минус рас- } \\
\text { ходы» }\end{array}$ & от $1 \%$ до $6 \%$ \\
\hline Чувашская Республика & $5 \%$ и $12 \%$ & не установлены \\
\hline Чукотский автономный округ & $5 \%$ и $10 \%$ & $2 \%$ и $4 \%$ \\
\hline ЯНAO & $\begin{array}{l}5 \text { \% установлена ставка для всех нало- } \\
\text { гоплательщиков, которые применяют } \\
\text { УСН с объектом «Доходы минус рас- } \\
\text { ходы» }\end{array}$ & не установлены \\
\hline Ярославская область & $5 \%$ и $10 \%$ & $4 \%$ \\
\hline
\end{tabular}


В 2017 г. изменения коснулись также перераспределения ставок по налогу на прибыль в федеральный и региональный бюджеты: $3 \%$ от налога теперь зачисляется в федеральный бюджет; $17 \%$ - в бюджет субъекта РФ. Основной целью бюджетно-налоговой политики государства является снижение межрегиональной дифференциации налогового бремени по регионам и налоговой нагрузки на валовой региональный продукт. Саморазвитие региональной экономической системы определяется способностью территориальной общины формировать фонды собственных финансовых ресурсов, обеспечивающих стабилизацию финансовой базы региона. Это предполагает определенную финансовую самостоятельность и независимость законодательных и исполнительных органов власти. Именно поэтому в качестве основной проблемы реализации бюджетно-налоговой стратегии выступает разделение полномочий между федеральными и региональными властями: перечень региональных и местных налогов является закрытым; порядок расчета налогооблагаемой базы исчисления законодательно определен; отсутствуют полномочия по регулированию региональной налоговой системы [6].

Ряд объектов имущества, подлежащих налогообложению, предпринимателю выгодно регистрировать как физическому лицу, поскольку только в этом случае он может воспользоваться льготами. Например, льготы для лиц пенсионного возраста, для участников войн предусмотрены в части налогообложения налогом на имущество. Для многодетных матерей в некоторых регионах, таких, как г. Москва, установлены льготы по налогу на имущество.

С целью совершенствования механизмов налогообложения необходимо установить равные права как предпринимателям, так и физическим лицам, поскольку грань использования имущества в предпринимательской деятельности является достаточно тонкой. Льготы предоставляются на основании заявления и подтверждающих документов, документы необходимо подавать не позднее 1 марта текущего года.

Существуют также отдельные региональные льготы, которые применяются для физических и юридических лиц, в частности, большегрузные автомобили могут снизить до нуля плату за вред, который причиняется транспортным дорогам, так называемые платежи «Платон», подобные льготы могут применяться как для физических лиц (ст. 361.1 НК РФ), так и для юридических лиц (п. 2 ст. 362 НК РФ). Однако срок льготы ограничен, она действует до 2019 года.

Таким образом, можно констатировать, что государством в сфере бюджетно-налоговой политики была проделана достаточно большая работа по развитию предпринимательства фискальными инструментами. Однако, как показал проведенный анализ, набор льгот, предусмотренных действующим законодательством и имеющих целью стимулировать предпринимательскую активность, свидетельствует об их бессистемности и отсутствии должного экономического обоснования введения в разрезе отраслей и регионов. Как показывает анализ, отсутствует четкая классификация налоговых льгот, формализация целей и сроков их введения. Практически единственными субъектами налоговых льгот, для которых определены сроки, являются резиденты ОЭЗ.

Вместе с тем следует отметить, что налоговая политика современной России превратилась в конкуренцию льгот, название которых сложно запомнить, а новые принимаются без оценки эффективности предыдущих. Налоговая политика сводится к гонке за неработающими и не обеспечивающими экономическую конкурентоспособность льготами. Региональное налогообложение характеризуется целым комплексом проблем, требующих комплексного подхода для их решения. Имеют место определенные недоработки в части налогового администрирования, в частности, не ведутся статистические исследования, позволяющие сказать, каким образом меры поддержки повлияли реально на развитие регионального предпринимательства в стране. Отсутствует глубокий анализ эффективности налоговых льгот, их влияния на экономический рост.

По мнению авторов, Министерством финансов РФ должны быть разработаны методические рекомендации по анализу и оценке налоговых льгот, установленных законами субъектов Федерации о налогах. Должны быть 
четко определены параметры оценки объемов налоговых льгот, методология оценки, методы прогнозирования объема льгот, целевые показатели и индикаторы, позволяющие установить социально-экономическую и бюджетную эффективность.

\section{ПРИМЕЧАНИЯ}

${ }^{1}$ C 2014 по 2016 г. доля прибыли в структуре национального дохода выросла на 3,4 п.п. до уровня $42,3 \%$.

2 Проблемы налогообложения сельскохозяйственных производителей подробно исследованы авторами в работе [20].

3 Особая экономическая зона определяется как ограниченная территория в регионах с особым юридическим статусом и льготными экономическими условиями для предпринимателей.

4 ОЭЗ «Липецк» первой из отечественных особых экономических зон в 2016 г. вышла на самоокупаемость.

5 В 2016 г. насчитывалось 32 особые экономические зоны, в 2017 г. осталось 26.

6 ТОСЭР - экономическая зона, где предоставляется особый правовой режим осуществления предпринимательской деятельности, в том числе льготное налогообложение на 10-летний период.

\section{СПИСОК ЛИТЕРАТУРЫ}

1. Бархатов, В. И. Успешность быстрорастущих предприятий среднего бизнеса в России / В. И. Бархатов, Д. А. Плетнев // Вестник Пермского национального исследовательского политехнического университета. Социально-экономические науки. - 2015. - № 4. C. $65-81$.

2. Белова, И. А. Налоговая нагрузка и успешность малых и средних предприятий в России / И. А. Белова // Вестник Челябинского государственного университета. - 2017. - № 2 (398). C. $98-108$.

3. Блинов, А. О. Диагностика развития малого предпринимательства в России / А. О. Блинов, О. С. Рудакова // Экономика. Налоги. Право. 2014. - № 4. - С. 62-66.

4. Гладковская, Е. Н. Оценка повышения финансовой самостоятельности бюджета внутригородского района: налоговый аспект / Е. Н. Гладковская, Т. В. Максимова // Фундаментальные исследования. -2016. - № 9-2. - С. 334-339.

5. Зайцев, М. М. Теоретические основы модели бюджетно-налогового федерализма в Российской Федерации: сущность, принципы, генезис
/ М. М. Зайцев // Актуальные проблемы российского права. - 2017. - № 1. - С. 109-115.

6. Карпова, Г. Н. Проблемные вопросы распределения налоговых поступлений по уровням бюджета / Г. Н. Карпова // Экономика: вчера, сегодня, завтра. -2016. - № 8. - С. 243-256.

7. Мишурова, И. В. Развитие малого и среднего предпринимательства как условие долговременного роста региональной экономики / И. В. Мишурова // Terra Economicus. - 2012. - T. 10, № 2-2. C. $166-170$.

8. Николаева, Е. В. Институциональные факторы успешности предприятий среднего бизнеса в Челябинской области / Е. В. Николаева, И. А. Белова // Вестник Челябинского государственного университета. - 2014. - № 21 (350). - С. 159-176.

9. О территориях опережающего социально-экономического развития в Российской Федерации : федер. закон от 29.12.2014 № 473-Ф3. - Доступ из справ.-правовой системы «КонсультантПлюс».

10. Об особых экономических зонах в Российской Федерации : федер. закон от 22.07.2005 № 116Ф3. - Доступ из справ.-правовой системы «КонсультантПлюс».

11. Пансков, В. Г. О некоторых неотложных мерах налогового стимулирования инвестиционной активности в российской экономике / В. Г. Пансков // Белорусский экономический журнал. 2013. - № 3. - С. 61-72.

12. Печенская, М. А. Межбюджетное распределение налогов в России: концентрация полномочий или децентрализация управления / М. А. Печенская, Т. В. Ускова // Экономика региона. - 2016. № 3. - С. 875-886.

13. Проект «Основные направления бюджетной, налоговой и таможенно-тарифной политики на 2018 год и на плановый период 2019 и 2020 гг.» // Официальный сайт Министерства финансов Российской Федерации. - Электрон. текстовые дан. - Режим доступа: https://www.minfin.ru/ru/document/?id_4=119695 (дата обращения: 12.11.2017). - Загл. с экрана.

14. Рейтинг социально-экономического положения субъектов РФ по итогам 2016 года // РИА рейтинг. - Электрон. текстовые дан. - Режим доступа: http://riarating.ru/infografika/20170530/630063754. html (дата обращения: 15.11.2017). - Загл. с экрана.

15. Россия. Особые экономические зоны // Официальный сайт проекта. - Электрон. текстовые дан. - Режим доступа: http://www.russez.ru/. Загл. с экрана.

16. Скворцова, А. С. Полномочия субъектов Российской Федерации по установлению региональных налогов: правовой анализ / А. С. Скворцова // Пермский финансовый журнал. - 2015. - № 1 (12). - C. 95-111. 
17. Третьякова, Ю. Н. Налоговое стимулирование инновационной деятельности в РФ / Ю. Н. Третьякова // Молодой ученый. - 2015. - № 7.-С. 499-502.

18. Фаляхов, Р. Зоны особых затрат / Р. Фаляхов // Газета.RU. - Электрон. текстовые дан. - Peжим доступа: https://www.gazeta.ru/business/2017/ 04/10/10619267.shtml. - Загл. с экрана.

19. Barhatov, V. I. Key Success Factors and Barriers for Small Businesses: Comparative Analysis / V. I. Barhatov, D. A. Pletnev, A. Campa // Procedia Social and Behavioral Sciences. - 2016. - No. 221. P. $29-38$.

20. Tendencies, problems and prospects of the balanced and competitive Development of agrarian Entrepreneurship in Russia / I. P. Dovbiy, I. V. Mitrofanova, E. G. Russkova, E. A. Shkarupa, V. V. Batmanova, I. A. Mitrofanova // Revista Galega de Economia. - 2017. -Vol. 26-2. - P. 97-112.

\section{REFERENCES}

1. Barkhatov V.I., Pletnev D.A. Uspeshnost bystrorastushchikh predpriyatiy srednego biznesa $\mathrm{V}$ Rossii [The Success of Fast-Growing Medium-Sized Enterprises in Russia]. Vestnik Permskogo natsionalnogo issledovatelskogo politekhnicheskogo universiteta. Sotsialno-ekonomicheskie nauki, 2015, no. 4 , pp. 65-81.

2. Belova I.A. Nalogovaya nagruzka i uspeshnost malykh i srednikh predpriyatiy v Rossii [The Tax Burden and the Success of Small and MediumSized Enterprises in Russia]. Vestnik Chelyabinskogo gosudarstvennogo universiteta, 2017, no. 2 (398), pp. $98-108$.

3. Blinov A.O., Rudakova O.S. Diagnostika razvitiya malogo predprinimatelstva $\mathrm{V}$ Rossii [Diagnosis of Small Business Development in Russia]. Ekonomika. Nalogi. Pravo, 2014, no. 4, pp. 62-66.

4. Gladkovskaya E.N., Maksimova T.V. Otsenka povysheniya finansovoy samostoyatelnosti byudzheta vnutrigorodskogo rayona: nalogovyy aspekt [Evaluation of Increasing Financial Autonomy of the Budget of the Inner City District: the Tax Aspect]. Fundamentalnye issledovaniya, 2016, no. 9-2, pp. 334-339.

5. Zaytsev M.M. Teoreticheskie osnovy modeli byudzhetno-nalogovogo federalizma v Rossiyskoy Federatsii: sushchnost, printsipy, genezis [Theoretical Foundations of the Model of Budgetary and Tax Federalism in the Russian Federation: Essence, Principles, Genesis]. Aktualnye problemy rossiyskogo 2017, no. 1, pp. 109-115.

6. Karpova G.N. Problemnye voprosy raspredeleniya nalogovykh postupleniy po urovnyam byudzheta [The Tax Revenues Distribution Between the Budget Levels]. Ekonomika: vchera, segodnya, zavtra, 2016, no. 8, pp. 243-256.

7. Mishurova I.V. Razvitie malogo i srednego predprinimatelstva kak uslovie dolgovremennogo rosta regionalnoy ekonomiki [Development of Small and Medium Enterprises as a Condition of Long-Term Regional Economic Growth]. Terra Economicus, 2012, vol. 10, no. 2-2, pp. 166-170.

8. Nikolaeva E.V., Belova I.A. Institutsionalnye faktory uspeshnosti predpriyatiy srednego biznesa $\mathrm{V}$ Chelyabinskoy oblasti [Institutional Factors of the Success of Medium-Sized Enterprises in the Chelyabinsk Region]. Vestnik Chelyabinskogo gosudarstvennogo universiteta, 2014, no. 21 (350), pp. 159-176.

9. Federalnyy zakon ot 29.12.2014g. № 473-FZ "O territoriyakh operezhayushchego sotsialnoekonomicheskogo razvitiya $v$ Rossiyskoy Federatsii" [Federal Law of December 29, 2014 no. 473-FL "On the Territories of Advanced Socio-Economic Development in the Russian Federation"]. Access from Reference Legal System "KonsultantPlyus".

10. Federalnyy zakon ot 22.07.2005g. № 116-FZ "Ob osobykh ekonomicheskikh zonakh v Rossiyskoy Federatsii" [On Special Economic Zones in the Russian Federation: Federal Law of July 22, 2005 no. 116-FL]. Access from Reference Legal System "KonsultantPlyus".

11. Panskov V.G. O nekotorykh neotlozhnykh merakh nalogovogo stimulirovaniya investitsionnoy aktivnosti v rossiyskoy ekonomike [About Some Urgent Measures of Tax Incentives of Investment Activity in the Russian Economy]. Belorusskiy ekonomicheskiy zhurnal, 2013, no. 3, pp. 61-72.

12. Pechenskaya M.A., Uskova T.V. Mezhbyudzhetnoe raspredelenie nalogov v Rossii: kontsentratsiya polnomochiy ili detsentralizatsiya upravleniya [The Tax Revenues Distribution in the Russian Federation: the Concentration of Powers or the Decentralization of Management]. Ekonomika regiona, 2016, no. 3, pp. 875-886.

13. Proekt «Osnovnye napravleniya byudzhetnoy, nalogovoy i tamozhenno-tarifnoy politiki na 2018 god i na planovyy period 2019 i 2020 gg. [The Project "Main Areas of the Budget, Tax and Customs Tariff Policy for 2018 and the Planning Period of 2019 and 2020"]. Ofitsialnyy sayt Ministerstva finansov Rossiyskoy Federatsii [Official Website of the Ministry of Finance of the Russian Federation]. URL: https://www.minfin.ru/ru/ document/?id_4=119695.

14. Reyting sotsialno-ekonomicheskogo polozheniya subyektov RF po itogam 2016 goda [Rating of the Socio-Economic Situation of the Subjects of the Russian Federation by the Results of 2016]. RIA rating. URL: http://riarating.ru/infografika/ 20170530/630063754.html. 
15. Rossiya. Osobye ekonomicheskie zony [Russia. Special Economic Zones]. Ofitsialnyy sayt proekta [Official Website of the Project]. URL: http:// www.russez.ru//.

16. Skvortsova A.S. Polnomochiya subyektov Rossiyskoy Federatsii po ustanovleniyu regionalnykh nalogov: pravovoy analiz [The Powers of the Federal Subjects of the Russian Federation to Establish Regional Taxes: Legal Analysis]. Permskiy finansovyy zhurnal, 2015, no. 1 (12), pp. 95-111.

17. Tretyakova Yu.N. Nalogovoe stimulirovanie innovatsionnoy deyatelnosti v RF [Tax Incentives of Innovative Activity in the Russian Federation]. Molodoy uchenyy, 2015, no. 7, pp. 499-502.
18. Falyakhov R. Zony osobykh zatrat [Zones of Special Costs]. Gazeta.RU. URL: https://www. gazeta.ru/business/2017/04/10/10619267.shtml? updated.

19. Barkhatov V.I., Pletnev D.A., Campa A. Key Success Factors and Barriers for Small Businesses: Comparative Analysis. Procedia - Social and Behavioral Sciences, 2016, no. 221, pp. 29-38.

20. Dovbiy I.P., Mitrofanova I.V., Russkova E.G., Shkarupa E.A., Batmanova V.V., Mitrofanova I.A. Tendencies, problems and prospects of the balanced and competitive Development of agrarian Entrepreneurship in Russia. Revista Galega de Economia, 2017, vol. 26-2, pp. 97-112.

\section{Information about the Authors}

Irina P. Dovbiy, Doctor of Sciences (Economics), Professor, Department of Economic Security, Higher School of Economics and Management, South Ural State University (National Research University), Prosp. Lenina, 76, 454080 Chelyabinsk, Russian Federation, betelgeyse@mail.ru.

Diba M. Dokhkilgova, Candidate of Sciences (Economics), Associate Professor, Department of Management of Regional Economy, Chechen State University, Sheripova St., 32, 364024, Grozny, Russian Federation, dibagrozny@mail.ru.

Natalya S. Dovbiy, Postgraduate Student, Department of Accounting, Analysis and Audit, Higher School of Economics and Management, South Ural State University (National Research University), Prosp. Lenina, 76, 454080 Chelyabinsk, Russian Federation, natasha_m92@mail.ru.

\section{Информация об авторах}

Ирина Павловна Довбий, доктор экономических наук, профессор кафедры экономической безопасности, Высшая школа экономики и управления, Южно-Уральский государственный университет (НИУ), просп. Ленина, 76, 454080 г. Челябинск, Российская Федерация, betelgeyse@mail.ru.

Диба Мажитовна Дохкильгова, кандидат экономических наук, доцент кафедры управления региональной экономикой, Чеченский государственный университет, ул. А. Шерипова, 32, 364024 г. Грозный, Российская Федерация, dibagrozny@mail.ru.

Наталья Сергеевна Довбий, аспирант кафедры бухгалтерского учета, анализа и аудита, Высшая школа экономики и управления, Южно-Уральский государственный университет (НИУ), просп. Ленина, 76, 454080 г. Челябинск, Российская Федерация, natasha_m92@mail.ru. 